\title{
Relationship between Emotional Intelligence of Head Nurses and Empowerment of Staff Nurses
}

\author{
Gehan Mohamed Mostafa, D.N.Sc ; Rasha Ibrahem Aly D.N.Sc,; Heba Emad \\ EL-Gazar, B.Sc
}

The Department. of Nursing Administration, Faculty of Nursing, Helwan University; Department of Nursing Administration, Faculty of Nursing, Port Said University;, Department of Nursing Administration, Faculty of Nursing Port Said University

\begin{abstract}
Background: Emotionally intelligent leadership has a great impact on staff performance.

Aim: The present study aims to study the relationship between emotional intelligence of head nurses and empowerment of staff nurses in Port Said hospitals.

Materials and Methods :A descriptive correlational study was utilized with a sample of (39) head nurses and their staff nurses (279) who were working in Port Said General Hospital and Port Said Health Insurance Hospitals. Data were collected by two questionnaire sheets, one for assessing head nurses emotional intelligence and the other for determining the level of their staff empowerment.
\end{abstract}

Results: Results revealed that all head nurses had average of emotional intelligence. Most emotionally intelligent head nurses behavior pertained to self motivation followed by selfawareness, social skills, empathy, and self-regulation. Also, the most of staff nurses were empowered.

Conclusion: In conclusion, there is a highly significant relationship between head nurses' emotional intelligence and staff nurses' empowerment. Therefore, it is recommended that, academic members have to develop training program on emotional intelligence as a managerial skills for head nurses. In addition to, head nurses should use emotionally intelligence leadership style and share the leadership power with nursing staff.

Keywords: Emotional intelligence, Empowerment, Head nurses, Staff nurses 


\section{Introduction}

THE world changes brought a need for health organizations and nursing leaders to response to these changes. Already in the 21 st century, several new leadership concepts have emerged as a means to achieve organizational goals, including the leaders/ managers need for emotional intelligence (Marquis, \& Huston, 2012). Developing a high degree of emotional intelligence may be the most important ingredient in effective leadership, more important than advanced nursing degree or even vast leadership experience. Managing emotions and relating to others in a positive way can have the most influential results (Clark, 2009).

Emotional intelligence has been defined as the capacity for recognizing one's own feelings and those of others, for motivating themselves, and for managing emotions well in themselves and in relationship (Mortiboys, 2012). Emotional intelligence has five elements. They are self-awareness, self-regulation, motivation, empathy and social competences. Self-awareness is the ability to recognize one's emotions, as well as how these impact on others. Selfregulation is the ability to control any disruptive emotions. Motivation refers to a drive to work toward a common goal. Empathy involves the ability to understand other peoples' emotions. Social skills refer to the ability to build relationships through finding common ground (Cox, Hill \& Lack, 2012).

Emotional intelligence is thought to be an important attribute of effective leaders (Rumsey, 2013). In this regard Lucas, Laschinger \& Wong (2008) added that emotional intelligence nursing leaders have strong relationship, management skills, and are more likely to empower their staff by being sensitive to their needs and make an effort to meet this needs to increase nurses feelings of empowerment. Nurses, like most people, want to have some power and to feel empowered; they want to be heard, to be recognized, to be valued, and to be respected. (Whitehead, Weiss, \& Tappen, 2010).

Empowerment is the process that facilitates the participation of others in decision making and taking action within an environment where there is equitable distribution of power (Wise, 2014) Empowering others requires supervisors to give their people opportunities to contribute knowledge and expertise and to encourage them to take new tasks and to improve their capabilities. It means allowing people to participate in planning their work, making decision and solving problems (Greer \& Plunkett, 2007). 


\section{Significance of the Study:}

Nursing leaders play a significant role in creating a positive work environment for nurses (Ritchie, Laschinger \& Wong, 2009). As, the head nurses in Port Said hospitals were seen to be easily anxious due to work stress, and the staff nurses were seen to be less interested in performing their assigned duties in their working unit. Studying the relationship between emotional intelligence of head nurses, and empowerment among their staff nurses has become more important.

\section{Aim of the study:}

Study the relationship between emotional intelligence of head nurses, and empowerment of staff nurses in Port Said hospitals.

\section{Materials and Methods}

Study Design: A descriptive correlation research design was used, carried out at two major hospitals in Port Said governorate; these are Port Said general hospital, which affiliated to ministry of health, and Port Said health insurance hospital (which divided to El-Tadamon health insurance hospital and El-Mabara health insurance hospital).

The subjects of this study included two groups; they were all head nurses (Convenient Sample: sampling technique) who were working in the study setting and their staff nurses.

\section{Data collection tools:}

Two tools were used to collect data for this study.

TOOL (I): Emotional intelligence questionnaire, this tool consisted of two parts:

This part included head nurses' personal characteristics as name, age, gender, level of Part I: education and years of experiences.

Part II: This part used for assessing emotional intelligence of the head nurses. It was developed and adopted by Abdel-Aleem (2013) based on the tool that adopted from Othman and Abdul-Samea (2001) and Mahmud (2002). This tool consists of 82 items which grouped in two dimensions: personal competences and social competences.

\section{A) Personal Competences:}

Included fifty questions (50) categorized under three clusters, namely; self- awareness (15 questions), self-regulation (18 questions) and self- motivation (17 questions).

\section{B) Social Competences:}

It included thirty-two questions categorized under two clusters, namely empathy (11 questions) and social skills (21 questions). 
TOOL (II): Empowerment questionnaire, this tool consisted of two parts

This part included staff nurses' personal characteristics as name, age, gender, level of Part I: education and years of experiences.

Part II: This part was utilized for assessing the staff nurse empowerment level. It was developed by Chandler (1986) and Laschingen (1999) and was adopted from Abdou (2009). This tool consists of 44 items with four subscales, which are related to access to opportunities (19 items), information (10 items), support (8 items) and resources (7 items).

\section{Results}

Table (1) shows level of emotional intelligence among head nurses. According to the table, all head nurses have average of emotional intelligence, with the mean of (75.6 \pm 6.4$)$. The mean of total personal competencies among head nurses was (74.6 \pm 6.7$)$ whereas, the mean of total social competencies among head nurses was (77.4 \pm 8.9$)$.

Table (2) indicates the relation between head nurses' emotional intelligence and their personal characteristics. As table indicates, head nurses who have experience 30 years or more and their age 50 years old or more have the highest mean score of emotional intelligence. Regarding the educational level, head nurses who have nursing diploma have the highest mean score of emotional intelligence.

Table (3) reveals empowerment level among staff nurses. (82.4\%) of staff nurses were empowered, the highest percent of empowerment was shown in access to opportunities $(85.7 \%)$, while the lowest percent of empowerment showed in access to resources $(71.3 \%)$.

Table (4) reveals the relation between staff nurses' empowerment level and their personal characteristics. As table indicates, the highest percentage of empowered staff nurses $(60.4 \%)$ at the age 20 to 30 years old. Also, this table reveals that $52.2 \%$ of empowered staff nurses have experience more than one year and less than ten years. $73.9 \%$ of empowered staff nurses have nursing diploma.

Table (5) shows a correlation between head nurses' emotional intelligence items and staffnurses' total empowerment. As shown in this table, there was statistically significant relationship between (self-awareness, motivation, empathy and social skills) emotional intelligent behavior of head nurses and empowering their staff nurses $(\mathrm{P}=0.001,0.004,0.006$, 0.0001 respectively). 
Table (6) shows a correlation between staff-nurses' empowerment items and head nurses' emotional intelligence. As table indicates, there was statistically significant relationship between staff nurses' empowerment items access to (opportunities, information, support and resources $)$ and their head nurses' emotional intelligence $(\mathrm{P}=0.0001,0.006,0.003,0.001$ respectively).

Table (7) display a correlation between head nurses' emotional intelligence and staff nurses' empowerment. According to the table, there was extremely highly statistically significant relationship between head nurses' emotional intelligence and staff nurses' empowerment $(\mathrm{P}=0.0001)$.

\section{Discussion}

Currently, there is growing interest in developing emotional intelligence in health care organizations, as it becomes critical to the future health care leaders (Marshall, 2011). It was believed that the most effective nurse leaders have a high degree of emotional intelligence (Dubrin, 2013). Nurses' perception that their leaders have emotionally intelligent leadership behaviors has a strong effect on their feelings of empowerment, which is an important leadership strategy for creating an effective workplace and increasing the organization productivity (Ritchie et al, 2009).

Regarding head nurses emotional intelligence, the findings of the present study revealed that all head nurses had average of emotional intelligence. This finding might be due to the nature of their work environment as empathy, social dialogue and building relationship dominate in health care environments. This finding is supported by Feather (2009) who studied emotional intelligence and its relation to nursing leaders and indicated that leaders of health care have high emotional intelligence relating to the nature of the profession. In the same context Chism (2013) reported that nursing leaders' have high emotional intelligence. In contrast with, the findings of a study done by Hoar (2011) revealed weakness in New York nurse leaders emotional intelligence abilities.

The findings of the present study revealed that the most emotional intelligence head nurses behavior pertained to motivation followed by self-awareness, social skills, empathy, and self-regulation. In this regard, Abdel-Aleem (2013) reported that motivation was the highest emotional intelligence head nurses behavior. Whereas, Senyuva, Kaya, Isik \& Bodur (2013) concluded that the highest average pertained to self-awareness. 
Regarding to the relation between emotional intelligence and head nurses' personal characteristics; the present study was indicated that the older and more experience head nurses' were more emotionally intelligent than younger and less experience head nurses. These findings agreed with Abdel-Aleem (2013) who concluded that head-nurses who have 35 years or more and have 20 years of experience or more are more emotionally intelligent. Also, Reece (2012) mentioned that emotional intelligence is a learnable construct and can increase throughout the life span. This finding opposing the results of Gonzalez (2013) who reported that no relation was found between the length of years in healthcare and emotional intelligence among nursing leaders in Arizona.

Concerning educational qualification, the present study revealed that head nurses who have nursing diploma have the highest mean score of emotional intelligence. These findings are congruent with Abdel-Aleem (2013) who reported head-nurses who have nursing diploma are more emotionally intelligent. Meanwhile, this finding is in contraction with Hoar (2011) who indicated that nurse leaders who earned highest nursing degree had a higher emotional intelligence score.

Regarding to nursing staff empowerment, the findings of the present study revealed that the majority of staff nurses were empowered. These findings were congruent with that of Istomina et al. (2011) who found staff nurses were empowered with high level. Furthermore, Brody, Barnes, Ruble \& Sakowski (2012) showed that the most common theme from interviews with all staff nurses was empowerment. In comparison with Bish, Kenny \& Nay (2012) their result reported that staff nurses were moderately empowered.

The findings of the present study showed that staff nurses are more empowered in access to opportunity, followed by information, then support, and finally resources. This finding consistent with that of Zurmehly, Martin \& Fitzpatrick (2009) who stated that staff nurses are more empowered in access to opportunities and less empowered in resources. These findings were in contradiction with Bish et al. (2012) who reported that nurses in Victorian rural health services had greater access to support.

Regarding the relation between empowerment and staff nurses' personal characteristics; the study findings revealed that younger nurses are more empowered than older nurses. This is the same view of Ning, Zhong, Libo \& Qiejie (2009) who clarified that empowerment was perceived when nurses were younger. This is in contrast with Zurmehly et al. (2009) who 
reported that Ohio state nurses between 50 and 60 years old had higher levels of empowerment.

Concerning staff nurses years of experience, the finding revealed that staff nurses who spend less than ten years were more empowered than nurses who spend more time in work. This finding disagreed with Aly (2007) who indicated that there was a positive relationship between staff nurses empowerment and their years of experience in their current job. Regarding educational qualification, the study findings found that more empowered staff nurses have nursing diploma. These findings were in contradiction with Istomina et al. (2011), who found that nurses with higher education felt more empowered at their work.

The findings of the present study clarified that there is a statistically significant relationship between most of head nurses' emotional intelligence components (selfawareness, motivation, empathy, and social skills) and staff-nurses' empowerment. This finding was in accordance with Ritchie et al (2009) who stated that all clusters of emotional intelligent leadership behavior were related to their staff nurses empowerment. Also, Lucas et al, (2008) found that staff nurse's empowerment was strongly related to emotional intelligence components. In the same context the finding also revealed that there is no statistically significant relationship between head nurses' self-regulation behavior and staff-nurses' empowerment.

Also, the findings of the present study clarified that there is a statistically significant relationship between staff-nurses' empowerment factors (opportunities, information, support, and resources) and head nurses' emotional intelligence. These findings go on the same line with Lucas et al, (2008) who prove that access to opportunities, information, support and resources was most strongly related to overall emotional intelligence.

Regarding the relationship between head-nurses' emotional intelligence and staff nurses empowerment; the findings indicated that there is extremely high statistically significant relationship between head nurses' emotional intelligence and staff nurses' empowerment. This finding goes in the same line with those of Ritchie et al (2009) who found that staff nurses who felt that their front line leader exhibited emotionally intelligent leadership behavior reported greater access to workplace empowerment. In addition to, Parolini (2005) who asserted that leader's emotional intelligence meet the follower's need for empowerment through achievement, growth, and development. 


\section{Conclusion:}

In the light of the main study findings, it was concluded that all head nurses have average emotional intelligence and their staff nurses were highly empowered. There was extremely highly statistically significant relationship between head nurses' emotional intelligence and staff nurses' empowerment in Port Said hospitals.

\section{Recommendations:}

Based on the findings of this study, the following recommendations are suggested:

1. For academic members in nursing faculties:

- Develop training program on emotional intelligence as a managerial skills for head

- Integrate emotional intelligence courses into the nursing curriculum to increase nurses' level of emotional intelligence.

2. For medical and nursing administrators in health care organizations:

- Develop hospital social committees and motivate head nurses to share in it.

- Identify empowerment barriers in the work environment and create empowerment strategy.

3. For each head of department in health organizations:

- Using emotionally intelligence leadership style.

- $\quad$ Share the leadership power with nursing staff.

4. For staff nurses in health organizations:

- $\quad$ Search about new knowledge, learn new skills and be up to date.

- $\quad$ Share in department and organizational decisions. 


\section{References}

Abdel-Aleem, M.M. (2013). Relationship between emotional intelligence, conflict resolution style and group cohesiveness among nurses (Unpublished Doctorate's thesis). Port-Said University, Egypt.

Abdou, S.M. (2009). Assess stress and empowerment among nurse interns during the internship year at Mansoura university hospitals (Unpublished Master's thesis). Mansoura University, Egypt.

Aly, R.I. (2007). The Relationship between leadership styles of the head nurses and staff nurses empowerment and job satisfaction (Unpublished Master's thesis). Port Said University, Egypt.

Bish, M., Kenny, A. \& Nay, R. (2012). Perceptions of structural empowerment: nurse leaders in rural health services. Journal of Nursing Management, 22(1), 29-37. Retrieved from: http://www.onlinelibrary.wiley.com.

Brody, A.A., Barnes, K., Ruble, C., \& Sakowski, J. (2012). Evidence based practice councils: potential path to staff nurse empowerment and leadership growth. Journal of Nursing Administration, 42(1), 28-33. Retrieved from: http://www.ovid.com.

Castro, F., Gomes, J., \& Sousa, F.C. (2012). Do intelligence leaders make a difference? The effect of leaders 'emotional intelligence on followers' creativity. Creativity and innovation management, 21(2), 177-182. Retrieved from: http://www.onlinelibrary.wiley.com.

Chism, L. A. (2013). The doctor of nursing practice: A guide book for role development and professional issues $\left(2^{\text {nd }}\right.$ ed). U.S.A: Jones and Bartlett Publishers.

Clark, C. C. (2009). Creative nursing leadership and management. U.S.A: Jones and Bartlett Publishers.

Cox, C. L., Hill, M. C., \& Lack, V.M. (2012). Advanced practice in health care: Skills for nurses and allied health professionals. USA, Canada: Routledge.

Dubrin, A. J. (2013). Leadership: Research findings, practice and skills ( $7^{\text {th }}$ ed.). USA: SouthWestern Cengage Learning.

Feather, R. (2009). Emotional intelligence in relation to nursing leadership? Does it matter. Journal of Nursing Management, 17(3), 376-382. Retrieved from: http://www.onlinelibrary.wiley.com.

Greer, C.R., \& Plunkett, W.R. (2007). Supervisory management (1 $11^{\text {th }}$ ed.). New Jersey: Pearson Education Inc.

Gonzalez, U.S. (2013). The relationship between a nurse leaders emotional intelligence and followers job satisfaction (Doctorate's thesis, Grand Canyon University, Arizona, USA). Retrieved from: http://www. Proquest.com.

Helaly, S.H. (2013). Emotional intelligence and its relation to nursing performance among nurses at Mansoura university hospital and urology and nephrology center (Unpublished Doctorate's thesis). Mansoura University, Egypt.

Hoar, P.A. (2011). Nurse leaders emotional intelligence, staff nurse satisfaction, and staff nurse retention (Doctorate's thesis, ColumbiaUniversity, New York, USA). Retrieved from: http://www. Proquest.com. 
Istomina, N., Suominen, T., Razbadauskas, A., Martinkenas, A., Kuokkanen, L., \& LeinoKilpi, H. (2011). Lithuanian nurses' assessments of their empowerment. Scandinavian Journal of Caring Sciences, 26(1), 3- 11. Retrieved from:

http://www.onlinelibrary.wiley.com.

Lucas, V., laschinger, H.K., \& Wong, C. (2008). The impact of emotional intelligent leadership on staff nurses empowerment: The moderating effect of span of control. Journal of Nursing Management, 16(8), 964-973. Retrieved from: http://www.onlinelibrary.wiley.com.

Marquis, B.L., \& Huston, C.J. (2012). Leadership roles and management functions in nursing: Theory and application ( $7^{\text {th }}$ ed.). Philadelphia: Lippincott Williams\& Wilkins.

Marshall, E.S. (2011). Transformational leadership in nursing: From expert clinician to influential leader. USA: Springer Publishing Company

Mortiboys, A. (2012). Teaching with emotional intelligence: A step by step guide for higher and further education professionals $\left(2^{\text {nd }} \mathrm{ed}\right.$.). USA, Canada: Routledge.

iejie, L. (2009). The impact of nurse empowerment on Ning, S., Zhong, H., Libo, W., \&Q job satisfaction. Journal of Advanced Nursing, 65(12), 2642-2648. Retrieved from: http://www.onlinelibrary.wiley.com.

Parolini, J.L. (2005). Investigating the relationships among emotional intelligence servant leadership behaviors and servant leadership culture (Doctorate's thesis, Regent University, Virginia Beach, USA). Available at: http://www. regent.edu.com.

Reece, B.L. (2012). Human relations: Principle and Practice $\left(7^{\text {th }}\right.$ ed.). U.S.A: South Western Cengage learning.

Ritchie, C.Y., laschinger, H.K., \& Wong, C. (2009). The effect of emotionally intelligent leadership behavior on emergency staff nurses workplace empowerment and organizational commitment .Nursing leadership, l22(1), 70- 81. Retrieved from: http://www.longwood.com.

Rumsey, M. G. (2013). The Oxford handbook of leadership. USA: Oxford university press.

Senyuva, E., Kaya, H., Isik, B., \& Bodur, G. (2013). Relationship between self compassion and emotional intelligence in nursing students. International Journal of nursing practice, 16(4), 366-373. Retrieved from: http://www.onlinelibrary.wiley.com.

Whitehead, D.K., Weiss, S.A., \& Tappen, R.M. (2010). Essentials of nursing leadership and management ( $5^{\text {th }}$ ed.). Philadelphia: F. A. Davis Company.

Wise, P.S.Y. (2014): Leading \&managing in nursing ( $5^{\text {th }}$ ed.). USA: El-Sevier Mosby Inc Zurmehly, J., Martin, P. \& Fitzpatrick, J.J. (2009). Registered nurse empowerment and intent to leave current position and profesion. Journal of Nursing Management, 17(3), 383-391.

Retrieved from: http://www.researchgate.net. 
Table (1): Emotional intelligence among head nurses $(\mathrm{N}=39)$.

\begin{tabular}{|l|c|c|c|c||}
\hline \multicolumn{1}{|c|}{ Emotional intelligence } & No. & \% & Min-Max & Mean \pm SD \\
\hline Personal competencies: & 38 & 97.4 & $54.7-93.3$ & $(77.8 \pm 8.9)$ \\
Self-awareness & 27 & 69.2 & $50.0-85.6$ & $(65.6 \pm 9.4)$ \\
Self-regulation & 39 & 100 & $63.5-95.3$ & $(80.4 \pm 8.8)$ \\
Motivation & 39 & 100 & $60.8-89.4$ & $74.6 \pm 6.7$ \\
\hline Total personal competencies & 37 & 94.9 & $47.3-92.7$ & $(76.2 \pm 10.4)$ \\
\hline Social competencies: & 38 & 97.4 & $59.0-96.2$ & $(78.5 \pm 10.3)$ \\
Empathy & 39 & 100 & $61.0-94.5$ & $77.4 \pm 8.9$ \\
Social skills & $\mathbf{3 9}$ & $\mathbf{1 0 0}$ & $\mathbf{6 5 . 1 - 9 1 . 5}$ & $\mathbf{( 7 5 . 6 \pm 6 . 4 )}$ \\
\hline Total social competencies & & & & \\
\hline Total emotional intelligence & & &
\end{tabular}

Table (2): Relations between head nurses' emotional intelligence and their personal characteristics

\begin{tabular}{|c|c|c|c|}
\hline Personal characteristics & $\mathbf{N}$ & $\begin{array}{l}\text { Mean Intelligence of } \\
\text { Head nurses } \\
(\mathbf{N}=39)\end{array}$ & Significance \\
\hline \multicolumn{3}{|l|}{ Place of work } & \multirow{4}{*}{$\begin{array}{l}F=2.493 \\
P=0.097\end{array}$} \\
\hline El-Tadamon & 10 & $77.3 \pm 6.1$ & \\
\hline El-Mabara & 13 & $72.5 \pm 5.6$ & \\
\hline Port Said General hospital & 16 & $77.1 \pm 6.6$ & \\
\hline \multicolumn{3}{|l|}{ Gender } & \multirow{3}{*}{-NA- } \\
\hline Male & 1 & -- & \\
\hline Female & 38 & $75.5 \pm 6.4$ & \\
\hline \multicolumn{3}{|l|}{ Age (years) } & \multirow{5}{*}{$\begin{array}{c}\mathrm{F}=0.91 \\
\mathrm{P}=0.446\end{array}$} \\
\hline $20-$ & 14 & $75.9 \pm 5.8$ & \\
\hline $30-$ & 15 & $74.0 \pm 5.7$ & \\
\hline $40-$ & 3 & $74.9 \pm 10.6$ & \\
\hline $50-<60$ & 7 & $78.8 \pm 7.4$ & \\
\hline \multicolumn{3}{|l|}{ Qualification } & \multirow{5}{*}{$\begin{array}{l}F=1.063 \\
P=0.377\end{array}$} \\
\hline Nursing diploma & 28 & $76.3 \pm 7.1$ & \\
\hline Technical institute & 5 & $72.8 \pm 2.6$ & \\
\hline Faculty graduate & 5 & $73.1 \pm 3.0$ & \\
\hline Master Degree & 1 & -- & \\
\hline \multicolumn{3}{|l|}{$\begin{array}{l}\text { Duration of experience } \\
\text { (years) }\end{array}$} & \multirow{5}{*}{$\begin{array}{l}F=1.747 \\
P=0.175\end{array}$} \\
\hline Less than 10 & 13 & $76.3 \pm 5.5$ & \\
\hline $10-$ & 15 & $74.0 \pm 5.9$ & \\
\hline $20-$ & 5 & $73.1 \pm 7.9$ & \\
\hline $30-40$ & 6 & $80.2 \pm 6.9$ & \\
\hline
\end{tabular}


Table (3): Job empowerment among staff nurses $(\mathrm{N}=279)$.

\begin{tabular}{||l|c|c|c|c|c|c||}
\hline \multirow{2}{*}{\begin{tabular}{c} 
Empowerment \\
\multicolumn{1}{|c|}{ Items }
\end{tabular}} & \multicolumn{2}{|c|}{ Empowered } & \multicolumn{2}{c|}{$\begin{array}{c}\text { Not } \\
\text { empowered }\end{array}$} & \multirow{2}{*}{ Min- max } & $\begin{array}{c}\text { Mean\% } \\
\text { SD) }\end{array}$ \\
\cline { 2 - 5 } & No. & $\%$ & No. & $\%$ & & \\
\hline $\begin{array}{l}\text { Access to } \\
\text { opportunities }\end{array}$ & 239 & 85.7 & 40 & 14.3 & $35.8-97.9$ & $71.4 \pm 11.9$ \\
\hline $\begin{array}{l}\text { Access to } \\
\text { information }\end{array}$ & 216 & 77.4 & 63 & 22.6 & $22.0-100.0$ & $69.9 \pm 15.0$ \\
\hline Access to support & 209 & 74.9 & 70 & 25.1 & $35.0-100.0$ & $69.9 \pm 15.0$ \\
\hline Access to resources & 199 & 71.3 & 80 & 28.7 & $28.6-100.0$ & $68.2 \pm 16.0$ \\
\hline $\begin{array}{l}\text { Total } \\
\text { empowerment }\end{array}$ & 230 & 82.4 & 49 & 17.6 & $39.1-98.2$ & $70.3 \pm 11.2$ \\
\hline
\end{tabular}

Table (4): Relations between staff nurses' empowerment and their personal characteristics

\begin{tabular}{|c|c|c|c|c|c|}
\hline \multirow{3}{*}{ Personal characteristics } & \multicolumn{4}{|c|}{ Staff nurses (N=279) } & \multirow{3}{*}{ Significance } \\
\hline & \multicolumn{2}{|c|}{$\begin{array}{c}\text { No empowerment } \\
(<60 \%) \\
{[n=49]}\end{array}$} & \multicolumn{2}{|c|}{$\begin{array}{c}\text { Empowerment } \\
\text { (60\% or more) } \\
{[\mathrm{n}=\mathbf{2 3 0}]}\end{array}$} & \\
\hline & No. & $\%$ & No. & $\%$ & \\
\hline \multicolumn{5}{|l|}{ Place of work } & \multirow{4}{*}{$\begin{array}{l}X^{2}=6.559 \\
P=0.038^{*}\end{array}$} \\
\hline El-Tadamon & 4 & 8.2 & 38 & 16.5 & \\
\hline El-Mabara & 22 & 44.9 & 63 & 27.4 & \\
\hline Port Said General hospital & 23 & 46.9 & 129 & 56.1 & \\
\hline \multicolumn{5}{|l|}{ Age (years) } & \multirow{5}{*}{${ }^{M C} \mathrm{P}=0.3$} \\
\hline $20-$ & 35 & 71.4 & 139 & 60.4 & \\
\hline $30-$ & 12 & 24.6 & 62 & 27.0 & \\
\hline 40- & 1 & 2.0 & 20 & 8.7 & \\
\hline $50-\leq 60$ & 1 & 2.0 & 9 & 3.9 & \\
\hline \multicolumn{5}{|l|}{ Gender } & \multirow{3}{*}{$\begin{array}{l}X^{2}=0.094 \\
P=0.759\end{array}$} \\
\hline Male & 5 & 10.2 & 27 & 11.7 & \\
\hline Female & 44 & 89.8 & 203 & 88.3 & \\
\hline \multicolumn{5}{|l|}{ Qualification } & \multirow{4}{*}{${ }^{M C}{ }_{P}=0.547$} \\
\hline Nursing diploma & 40 & 81.6 & 170 & 73.9 & \\
\hline Technical institute & 7 & 14.3 & 49 & 21.3 & \\
\hline Faculty graduate & 2 & 4.1 & 11 & 4.8 & \\
\hline \multicolumn{5}{|l|}{$\begin{array}{l}\text { Duration of experience in } \\
\text { nursing (years) }\end{array}$} & \multirow{5}{*}{$\mathrm{MC}_{\mathrm{P}}=0.676$} \\
\hline $1-$ & 28 & 57.1 & 120 & 52.2 & \\
\hline $10-$ & 17 & 34.8 & 75 & 32.6 & \\
\hline $20-$ & 3 & 6.1 & 27 & 11.7 & \\
\hline $30-40$ & 1 & 2.0 & 8 & 3.5 & \\
\hline
\end{tabular}


Table (5): Correlation between head nurses emotional intelligence items and staff-nurses' empowerment.

\begin{tabular}{|l|c|c|}
\hline \multirow{2}{*}{\multicolumn{1}{|c|}{ Emotional intelligence Items }} & \multicolumn{2}{c|}{ Empowerment score } \\
\cline { 2 - 3 } & $\mathbf{R}$ & $\mathbf{P}$ \\
\hline Self-awareness & $\mathbf{0 . 2 0 8}$ & $\mathbf{0 . 0 0 1 *}$ \\
\hline Self-regulation & 0.096 & 0.112 \\
\hline Motivation & $\mathbf{0 . 1 7 4}$ & $\mathbf{0 . 0 0 4} *$ \\
\hline Empathy & $\mathbf{0 . 1 6 5}$ & $\mathbf{0 . 0 0 6}^{*}$ \\
\hline Social skills & $\mathbf{0 . 2 1 5}$ & $<\mathbf{0 . 0 0 0 1}^{*}$ \\
\hline
\end{tabular}

Table (6): Correlation between staff-nurses' empowerment items and head nurses emotional intelligence.

\begin{tabular}{|l|c|c|}
\hline \multirow{2}{*}{\multicolumn{1}{|c|}{ Items }} & \multicolumn{2}{c|}{ Emotional intelligence score } \\
\cline { 2 - 3 } & $\mathbf{R}$ & $\mathbf{P}$ \\
\hline Access to opportunities & 0.239 & $<0.0001^{*}$ \\
\hline Access to information & 0.165 & $0.006^{*}$ \\
\hline Access to support & 0.177 & $0.003^{*}$ \\
\hline Access to resources & 0.202 & $0.001^{*}$ \\
\hline
\end{tabular}

Table (7): Correlation between head nurses emotional intelligence and staff nurses empowerment.

\begin{tabular}{||l|c|c||}
\hline \multirow{2}{*}{ Item } & \multicolumn{2}{|c|}{ Job empowerment } \\
\cline { 2 - 3 } & $r$ & $p$ \\
\hline Emotional intelligence & 0.251 & $<0.0001^{*}$ \\
\hline
\end{tabular}

r: Spearman Rho correlation coefficient

** Highly significant at $\mathbf{P} \leq \mathbf{0 . 0 0 1}$

\footnotetext{
*significant at $\mathbf{P} \leq \mathbf{0 . 0 5}$

*** Extremely highly significant at $\mathbf{P} \leq \mathbf{0 . 0 0 0 1}$
} 
العلاقة بين الأكاء العاطقي لاي رئيسات هيئه التمريض والتمكين لاي الممرضات

د. جيهان ححمد احمد مصطفي، د. رشا ابر اهيم السيد علي ،هبه عماد السيد الجزار.

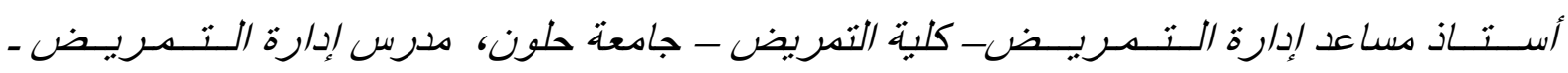

كلية التمريض - جامعة بورسعبي، بكالوربيوس تمريض - كلية التمربض - جامعة بورسعبب

\section{الخلاصة}

يؤثر الذكاء العاطفي للقائد علي اداء العاملين معـه، هدفت الدر اسـة الحاليـة الي تحديد العلاقة بين الذكاء العاطفي لدي رئيسات هيئه التمريض و التمكين لدي الممرضات بمستسقيات محافظه بورسعيد. وقد أجريت در اسـة وصفية تر ابطيـة بمستشفي بورسـيد العـام و مستشفي التامين الصـحي ببورسـيد شـارك فيها جميـع رئيسـات الوحدات التمريضـية وكـان عددهم وب و جميـع اعضــاء هيئه التمـريض العـاملين معهم وكـان عددهم YVq ممرضــهـ وقد تم استخدام اسـتبيانان الأول لقيـاس مسـتوي الذكاء العاطفي لدي رئيسات وحدات التمريض والثاني لتحديد مستوى التمكين لدي هيئه التمريض. وقد كثفت النتائج علي أن جميع رئيسات الوحدات التمريضية لديهن قدر مرضي من الذكاء العاطفي، وكان تحفيز الذات أعلى عو امل الذكاء العاطفي لديهن يليه الوعي بالذات، ثم المهار ات الاجتماعيـة يليها التعاطف

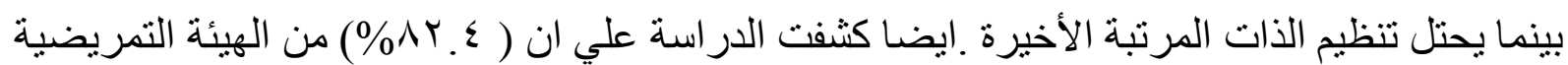
لديهن تمكين. و نستخلص من الدر اسة أن هنالك علاقة قويـه بين مستوي الذكاء العـاطفي لدي رئيسـات هيئه التمريض و التمكين لدي الممرضات. و لللك يوصى بتصميم بر امج تعليمية و تدريبية من قبل هيئه التدريس بكليات التمريض عن الذكاء الوجداني لرؤساء هيئه التمريض ، كمـا يجب أن يحرص رؤسـاء هيئه التمريض علي استخدام الذكاء العاطفي في القيادة وان يحفزن الهيئة التمريضية علي المشاركة في اتخاذ القر ار.

الكلمات اللاللة: الذكاء العاطفي، التمكين، رئبيات التهربض ،العيئة التصربضية 